\title{
POLITICAL BUSINESS CYCLE IN CZECH MUNICIPALITIES
}

\author{
Lucie Sedmihradská, Rudolf Kubík, Jakub Haas*
}

\begin{abstract}
:
The paper examines the political business cycle at the municipal level in the Czech Republic using data for 205 municipalities in the period 2001-2007. We introduce empirical models based on fixed-effects panel data regression testing the capital and current expenditure manipulation prior to elections. The results indicate significant increase in capital expenditures and significant decrease in current expenditures prior to elections. At the same time the manipulation with capital expenditures does not increase the probability of re-election for the incumbents in the Czech municipalities.
\end{abstract}

Keywords: political business cycle, local government, elections, Czech municipalities, panel data regressions.

JEL Classification: H72, D72, D78

\section{Introduction}

Rational political business cycle theory suggests that politicians increase government spending or decrease taxes in pre-election periods in order to signal their competence and to increase their re-election chances. This leads to a political business cycle in government revenues and expenditures. Czech municipalities gained substantial autonomy during the early 1990s in budgeting and in their expenditures; however, their autonomy with regard to revenues remains very low. At the same time, municipalities can dispose of their property independently and their borrowings are limited only indirectly. This permits convenient timing for some expenditures.

The objective of this paper is to test the main assumptions and conclusions of rational political business cycle theory in Czech municipalities and to analyze the influence of municipal council elections on municipal expenditures. We also examine whether municipal expenditures affect the probability of the re-election of incumbents, i.e. whether there are repeated victories of the same political parties or groupings.

In the next part of the paper the model of the rational political business cycle is demonstrated. In Section 3 the Czech municipalities are described from the point of view of their fiscal autonomy and financing. Sections 4 and 5 describe the data and model applied. In Section 6 we present the results obtained and in Section 7 we conclude.

* University of Economics, Prague (sedmih@vse.cz; rudolf.kubik@vse.cz; haasj@post.cz). Authors want to thank the Internal Grant Agency of the University of Economics in Prague for kind financial support of the Project No. 2/08 "Political Business Cycle at the Municipal Level in the Czech Republic". 


\section{The Model of Rational Political Business Cycle}

Some authors have focused on the analysis of the economic consequences of the political cycle since the 1940s (see Žák, 1998, p. 472). The first model was introduced by Nordhaus (1975), who described the choice between inflation and unemployment in the pre-election and post-election periods. Based on his model the character of economic policy is predictable: restrictive economic policy at the beginning of the cycle is substituted by expansive fiscal and monetary policy before the elections. The model showed, as well, that voters do not decide in favour of future generations and that the level of investment is sub-optimal because voters prefer tax cuts and transfers or increases in current expenditures.

The main weakness of the model is the assumption of adaptive expectations, which implies myopic voters. In fact, voters learn from past mistakes, so it is neither easy nor possible to play the same tricks on voters repeatedly (see Veiga and Veiga, 2007, pp. 46-47). Concerning economic policy tools, it is easier to manipulate public expenditures than to stimulate the economic cycle with a comprehensive fiscal or monetary policy (see Žák, 1998, p. 473). Moreover, execution of stabilization policy at the municipal level is not relevant (see Oates, 1991, pp. 263-264).

Models with rational expectations (Rogoff and Sibert, 1988; Rogoff, 1990 and others) assume that the political business cycle is mainly caused by the fact that the government knows about its real competency sooner than the voters. This leads to temporary information asymmetry.

According to the model of Rogoff and Sibert (1988) government is competent if it provides public goods as inexpensively as possible (i.e., with minimal taxes). See Table 1, which shows a series of the consequent steps. It is obvious that voters learn the truth about the full costs of the provided public goods after the elections.

Table 1

The Origin of Informational Asymmetry

\begin{tabular}{|c|c|}
\hline \multirow{3}{*}{ Period $\mathbf{t}$} & $\begin{array}{l}\text { The government sets the lump-sum tax rate. The voters evaluate the } \\
\text { competence of the government based on this rate. The government knows } \\
\text { whether and with which rate a distortion tax will have to be imposed in order to } \\
\text { cover all expenditures. }\end{array}$ \\
\hline & Elections. \\
\hline & $\begin{array}{l}\text { In case the revenues from the lump-sum tax do not cover all the expenditures, } \\
\text { the government imposes a distortion tax. }\end{array}$ \\
\hline Period $t+1$ & $\begin{array}{l}\text { The new government takes office and the same happens with the exception of } \\
\text { elections, which do not take place in the same year. }\end{array}$ \\
\hline
\end{tabular}

Source: based on Rogoff and Sibert, 1988, Table 1, p. 4.

The model therefore assumes that the government influences voters mainly through the tax cuts. The authors quoted another model, they constructed, which states that voters observe taxes and current spending before elections and investment after it (see Rogoff and Sibert, 1988, p. 13). This is consistent with Nordhaus's assumption of lower than optimal investments in the pre-election period. 
Generally, the models of political business cycle can be classified according to the characteristics of the voters and the politicians. Voters can be rational and well informed or irrational and poorly informed. Politicians can opportunistically maximize the votes or ideologically pursue their objectives (see Nordhaus, 1989, p. 2). A combination of these two criteria gives four main approaches of political business cycle theory together with a fifth type which Nordhaus (1989, pp. 5-6) calls differences in competence, which unlike the former four models does not assume that the politicians are perfectly competent, i.e. able to acquire all the information available and to use it effectively.

Veiga and Veiga (2007) use a different model when analyzing political cycles at the municipal level in Portugal. They regard manipulation with investment expenditures as a tool for re-election. Unlike Rogoff and Sibert's model, they suppose that voters observe investments before elections. They focused mainly on visible investments in tangible assets, e.g. reconstruction of roads and schools, construction of new churches or playgrounds. This model concerns manipulation with the structure of public expenditures rather than their volume.

Rosenberg (1992) followed a completely different approach. Local politicians may decide not to be re-elected but they can manipulate public spending so as to achieve benefits $(e . g$. jobs $)$ in the private sector after the election. Thus, politicians who do not want to be re-elected change the volume of public spending more than those who will run for re-election again. Rosenberg's hypothesis does not contradict an assumption of rational expectations, but it does contradict an assumption of adaptive expectations.

In recent years the empirical literature on political business cycles at the level of local governments has grown very rapidly and brought interesting results. Sakurai and Menezes-Filho (2008) explained that Brazilian voters can be manipulated both by investment and current expenditures. However, they highlighted the fact that the deviation from the average level is significant; the time aspects of the year of election are not.

Comparison of research results in different countries indicates that opportunistic, pre-election expenditure manipulation affects the probability of re-election similarly in both Brazilian and Portuguese municipalities (see Veiga and Veiga, 2007b), in Russian regional governor elections (see Akhmedov and Zhuravskaya, 2004) and in Colombian municipalities (see Drazen and Elsava, 2005). However, it is worthy to note that voters may penalize large deficits (see Drazen and Eslava, 2005).

Other models of the behaviour of municipal politicians take a different approach. Authors usually deal with real economic variables rather than aspects of public budgets. Cerda and Vergara (2007) proved that the unemployment rate and the output gap have a significant effect on the votes obtained by the incumbent. Their model also includes non-economic variables such as the crime rate.

Research of the political business cycle in the Czech Republic has to this point focused only on the national level and it has in part attributed opportunistic motives to the behaviour of Czech incumbents. After 2000, partial economic recoveries occurred before parliamentary elections, there was a tendency towards higher GDP growth than in the EU-15, and movements of selected public expenditure items along with the cyclically adjusted deficit were evident (see Štiková, 2008). 


\section{Czech Municipalities}

The Czech Republic is a unitary state with two tiers of local government - regions (14) and municipalities $(6,250)$. In comparison with other countries the number of municipalities is very high. The joint model of public administration is applied in the Czech Republic - municipalities provide some services on behalf of the state (i.e. central administration). Regarding the extent of delegated powers we differentiate among three types of municipalities:

1) those executing elementary delegated powers,

2) those executing broader elementary delegated powers, and

3) those executing extended delegated powers (i.e. municipalities of extended scope).

The third type has the broadest range of delegated powers so it covers public services for other municipalities of the two lower types. The type of delegated powers determines in considerable measure both revenues and expenditures (see Hemmings, 2006, pp. 6 and 13). For our analysis, we consider the third type, i.e. all the 205 municipalities of extended scope.

Since 1990 decentralization, especially fiscal decentralization has been in process in the Czech Republic. Although municipalities have already gained substantial power and independence in their decision-making on expenditures, on their budgets, on the disposal of municipal properties, and on how they deliver public services, their authority in the area of municipal revenues remains very low.

Municipalities dispose of very few independent revenue sources and those sources provide only small amounts of revenue. Their tax authority is negligible; they have discretion over local fees (representing 1.5\% of municipal revenues in 2007) and some discretion (which increased in 2009) over the property tax (representing $2 \%$ of municipal revenues). The majority of the tax revenues comes from shared tax revenues (personal income tax, corporate income tax and value added tax) distributed among the municipalities by the central government. The distribution is based on a formula in which the origin of the funds plays only an insignificant role. Thus, fiscal autonomy is very limited from the point of view of the tax authority. The situation is more satisfying regarding the conditionality of the revenue sources; only the grants (with the exception of the grant for the execution of the delegated powers) are conditional. About three quarters of the municipal revenues do not have any strings attached.

There is no direct limitation on municipal borrowing, so a municipality can use deficit financing as long as it is able to get a loan from a commercial bank. Due to the very small size of most of the municipalities, issuing bonds is a feasible option only for the largest municipalities. The Ministry of Finance merely monitors a set of debt related indicators to identify in advance municipalities which might have difficulties with debt management. At the same time municipalities can accumulate budget surpluses and use these funds at their discretion.

Current expenditures represent about $70 \%$ of municipal expenditures and to a great extent have a form of entitlement. Municipalities are much more independent in their decision-making on capital expenditures, which can be financed from a conditional grant, from own resources, from a loan or a combination of these resources. As long as the investment is not grant-financed, the municipality is fully independent in its decision on 
the realization of a particular investment and its timing. Therefore, our research on political business cycles at the municipal level is primarily interested in capital expenditures.

When examining political business cycles in the Czech Republic we attempted to determine what differences from the models described above are significant in building a robust model for Czech municipal incumbents, i.e. municipal council members, who are elected directly. An important fact in the analysis of political business cycles arises from the asymmetric position of the Czech municipalities. While standard models often focus on the ideological orientation of politicians (left-wing, centrist, right-wing), that orientation is not relevant in the Czech Republic. As the municipalities have little power to influence the tax rate or base, right-wing politicians do not have the possibility to reduce taxes. They can only appeal to voters through increases in public spending.

Even though municipal expenditures represent only a minority share of public sector expenditures (16\% in 2008), they should not be underestimated. Decisions of national level politicians are determined not only by the date of the general election at the state level but by other elections (e.g. municipal, regional or European parliamentary) as well. Municipal elections are connected with one-third of the senators' elections and the candidates for mayor often compete in both elections. Municipal elections also influence the power of politicians in the political parties. At the same time we have to take into account that since 1998 municipal elections take place in the same year as general elections to the Chamber of Deputies.

Czech specifics may contradict some aspects of Rosenberg's hypothesis. Although a mayor himself may not want to be re-elected, he or she will usually be a member of a particular political party or grouping that has no desire to lose power. So the party will present another candidate to be substituted for the incumbent and the former becomes the new voting leader. In such a case it is very difficult to include the subjective probability of re-election in the model.

Good timing in the manipulation of public spending and estimating in advance the timing of the effects of such spending are also important for a politician seeking re-election. A new road, reconstructed square or other visible investment project brings more votes if it is finished before the election. The astute politician must also recognize, however, that the process of reconstruction itself could alienate some voters. When speaking about differences from models described above it is necessary to analyze not only the year of an election but the year preceding the election as well.

\section{Data Characteristics}

The data panel covers 205 municipalities of extended scope for the years 2001-2007 (except for the capital Prague). Although the time series is quite short it covers two electoral years in 2002 and 2006 and enables us to analyze the development of municipal expenditures in electoral years and years prior to the elections.

The election dates are defined exogenously so that municipalities cannot influence them. In the data set we also consider municipalities (Plzeň, Most, Brno, Havírov) with exceptional elections (i.e. elections held in years other than 2002 and 2006). In the empirical models we use per capita data in 2001 constant prices in CZK. We used the final-consumption price index as it concerns both public sector consumption and public transfers to the private sector. 
Financial data were acquired from internal sources of the Czech Ministry of Finance and the information system Automated Budget Information System (ARIS). We would like to thank the employees of Ministry of Finance for their help. The data are based on the Czech budget classification, i.e. all the data are recorded on the cash principle. The data for winning political parties or groupings come from Balík (2008) for the period 2001-2005 and from the Czech statistical office for the period 2006-2007.

\section{Model Specification}

We have estimated empirical models in order to test for rational political business cycles at the municipal level in the Czech Republic. First, we considered the capital expenditures (Capex) as the dependent variable, since we expect Capex are the main target for incumbents' manipulations when they wish to signal their effectiveness prior to elections. Second, we estimated a model of current expenditures (Curex) to test whether Curex are also targets of manipulation to incumbents. We expect Curex to decrease prior to elections. Third, we introduce a model with Re-election as the dependent variable in order to test which variables increase the probability of re-election. In other words, we try to answer the question whether expenditure manipulation actually does influence voters. This variable will show whether the same political party or grouping managed to win re-election.

The following variables have been considered:

- Capex $(t)$ are municipal capital expenditures in year $t$. Our hypothesis is that Capex are increased before elections.

- Capex (t-1) are one-year, lagged capital expenditures. These are to take into account the autoregressive component of the time series.

- Curex $(t)$ are municipal current expenditures in year $t$. We expect them to have a negative impact on capital expenditures as incumbents attempt to reduce Curex in favour of capital expenditure. At the same time we apply Curex as a dependent variable to test whether they are decreased prior to elections.

- Curex (t-1) are lagged values of current expenditures included to take into account the autoregressive component of the time series.

- Elect $(t)$ is a dummy variable that takes the value 1 in election years and 0 in other years. By applying this variable we test the hypothesis that expenditures increase in election years.

- Elect $(t-1)$ is a dummy variable that takes the value 1 for the year prior to elections and 0 for other years. Application of this variable enables us to test the hypothesis that expenditures grow even in the pre-election years.

- Elect $(t+1)$ is a dummy variable that takes the value 1 for the year following the elections. We test the reduction of expenditures after the election.

- Grants are the current and capital grants received by a municipality during the year $t$. We expect them to have a positive impact on expenditures.

- Caprev are municipal revenues coming from the sale of assets (e.g. housing privatization or the sale of property rights in utilities companies). We expect them to have a positive impact on expenditures. 
- Taxrev are tax revenues that the municipality receives in year $t$; we expect them to have a positive impact on expenditures. This variable also captures the influence of the business cycle as the Taxrev are strongly dependent on the performance of the economy.

- Re-election $(t)$ is a dummy variable that takes the value of 1 for the year of elections in which the winning political party or grouping was re-elected, otherwise it takes the value of 0 .

- Re-election $(t-1)$ is a dummy variable that takes the value of 1 for the year prior to elections if the winning political party or grouping was re-elected.

Table 2

Summary Statistics of Variables (per capita in thousands of CZK, 1,435 observations)

\begin{tabular}{|l|r|r|r|r|c|}
\hline Variable & Mean & Median & Minimum & Maximum & Std. deviation \\
\hline Taxrev & 8.3035 & 8.1909 & 4.0409 & 18.508 & 1.7306 \\
\hline Capex & 5.5473 & 4.8619 & 0.38346 & 46.438 & 3.4436 \\
\hline Grants & 9.0838 & 8.3828 & 1.9713 & 43.021 & 4.1913 \\
\hline Curex & 15.632 & 15.167 & 7.0405 & 44.868 & 3.6757 \\
\hline Caprev & 1.3364 & 0.97716 & -0.0052078 & 9.4441 & 1.3255 \\
\hline
\end{tabular}

Source: ARIS, own calculations.

The empirical model can be summarized as follows:

$$
Y_{i t}=\sum_{j=1}^{p} \alpha_{j} Y_{i, t-1}+\sum_{j=1}^{k} \beta_{j} X_{j i t}+a_{i}+u_{i t} \quad i=1, \ldots, N t=1, \ldots, T,
$$

where $Y$ is the dependent variable, $p$ is the number of lags included in the model, $X$ are observed explanatory variables, index $i$ refers to the unit of observation, $t$ refers to the time period, $a$ is the individual effect of the municipality $i$, and $u$ is the disturbance term.

When using a dummy variable to estimate individual effects in a model with a lagged dependent variable and a short time series, which is the case here, one gets biased estimates. If there is a clear dominance of units $(\mathrm{N}=205)$ over time in the sample $(\mathrm{T}=7)$, which leads to inconsistent OLS (Ordinary Least Squares) estimates, one usually applies the GMM (Generalized Method of Moments) or IV (Instrumental Variable) against the LSDV (Least Square Dummy Variable) method. However, according to Judson and Owen (1996) these methods are not preferable in the case of relatively few (usually less than 10) time periods and in this case the corrected LSDV might give the best fit.

We applied the robust covariance matrix estimator suggested by Arellano (2003), which is suitable for the panel data set of small $\mathrm{T}$ and large $\mathrm{N}$ and $\mathrm{HAC}$ (heteroskedasticity and autocorrelation consistent). The Arellano estimator can be summarized as follows:

$$
\sum_{A}=\left(X^{\prime} X\right)^{-1}\left(\sum_{i=1}^{n} X_{t}^{\prime} \hat{u}_{i} \hat{u}_{i}^{\prime} X_{t}\right)\left(X^{\prime} X\right)^{-1}
$$

where $X$ is the matrix of regressors, denotes the vector of residuals for unit $i$, and $n$ is the number of cross-sectional units. Based on panel diagnostic tests, the fixedeffects model was preferred to random effects. The main indicators of fixed effects 
are relatively large values for the Hausman statistics and low values for the between standard deviations reported for each model. ${ }^{1}$

\section{Empirical Results}

The estimated models of both capital and current expenditures show strong evidence of the rational political business cycle and of incumbents' opportunistic behaviour in the Czech municipalities. Incumbents manipulate municipal expenditures significantly, with respect both to their volume and structure, in the course of the political cycle. Capital expenditures grow in both election and pre-election years, while the increase is bigger in the election year (about CZK 1,376, approximately EUR 55, per capita).

According to our assumptions, capital expenditures decrease in the post-election year. There is also a robust negative relationship between Capex and Curex, which shows the incumbent's tendency to achieve savings in current expenditures to promote capital expenditures prior to elections. This finding is consistent with other papers (e.g. Drazen and Eslava, 2005). See Table 3 for the results.

The results show that the relationship between municipal expenditures and elections over the phase of the political cycle is very strong. However, as we have used data for quite a short period doubts may arise as to whether the results might be biased by some events such as the flooding that occurred in a large part of the country in 2002 (i.e. the election year) or such as the modifications made in financing education in 2005 (i.e. the pre-election year). Our model cannot capture all these variables and the only solution to this problem is to prolong the time series as much as possible.

We are convinced that there is consistently a positive relation between the volume of expenditures (Capex or Curex) and the level of municipal income (Taxrev, Grants, Caprev). Changes in grants have the biggest impact on both current and capital expenditures.

Application of the two types of election variables, i.e. elect and re-election, enables us to determine the differences in the extent to which expenditure manipulation occurs in municipalities where the incumbents' party or grouping was reelected or not. In municipalities where the incumbent's party was re-elected, the increase in capital expenditures and the reduction in current expenditures are smoother than in the municipalities where re-election was not achieved, both in the election and pre-election periods.

This suggests that an increase in capital expenditures does not need to increase the probability of re-election. In order to test these findings and to test what can in fact increase an incumbent's chances to get re-elected, we estimated a logit fixed-effects model where the re-election dummy variable is a dependent variable.

1 Main results are reported below each model, complete panel diagnostic results are available on request by authors. 
Table 3

Estimates of the Capital and Current Expenditures Models (205 cross-sectional units, time-series length 7, 1,230 observations)

\begin{tabular}{|c|c|c|c|c|c|}
\hline $\begin{array}{l}\text { Dependent } \\
\text { variable }\end{array}$ & CAPEX & CAPEX & CAPEX & CUREX & CUREX \\
\hline const & $\begin{array}{c}0.299839 \\
(1.076)\end{array}$ & $\begin{array}{c}3.13972 \text { *** } \\
(0.886)\end{array}$ & $\begin{array}{c}0.642606 \\
(1.076)\end{array}$ & $\begin{array}{c}5.48163^{* * *} \\
(0.707)\end{array}$ & $\begin{array}{c}4.65143^{* * *} \\
(0.594)\end{array}$ \\
\hline Capex (t-1) & $\begin{array}{c}0.0643222 * * * \\
(0.023)\end{array}$ & $\begin{array}{c}0.0569557^{* *} \\
(0.025)\end{array}$ & $\begin{array}{c}0.0644768^{* * *} \\
(0.022)\end{array}$ & & \\
\hline Curex (t-1) & & & & $\begin{array}{c}0.169449^{* * *} \\
(0.017)\end{array}$ & $\begin{array}{c}0.1278422^{* * *} \\
(0.015)\end{array}$ \\
\hline Elect $(t)$ & $\begin{array}{c}1.37635^{\star * *} \\
(0.169)\end{array}$ & & $\begin{array}{c}1.01210^{* * *} \\
(0.203)\end{array}$ & $\begin{array}{c}-0.620812^{* * *} \\
(0.124)\end{array}$ & \\
\hline Elect $(t-1)$ & $\begin{array}{c}0.737137^{* * *} \\
(0.206)\end{array}$ & & $\begin{array}{c}0.340186 \\
(0.237)\end{array}$ & $\begin{array}{c}-1.72066^{* * *} \\
(0.167)\end{array}$ & \\
\hline Elect $(t+1)$ & & & $\begin{array}{c}-0.494546^{* * *} \\
(0.144)\end{array}$ & & \\
\hline Re-election (t) & & $\begin{array}{c}0.732862^{* * *} \\
(0.162)\end{array}$ & & & $\begin{array}{c}-0.243332^{* * *} \\
(0.089)\end{array}$ \\
\hline Re-election (t-1) & & $\begin{array}{c}0.0981041 \\
(0.224)\end{array}$ & & & $\begin{array}{c}-1.19832^{\star * *} \\
(0.141)\end{array}$ \\
\hline Taxrev & $\begin{array}{c}0.830402^{* * *} \\
(0.081)\end{array}$ & $\begin{array}{c}0.790495^{* * *} \\
(0.077)\end{array}$ & $\begin{array}{c}0.865472^{* * *} \\
(0.081)\end{array}$ & $\begin{array}{c}0.515909^{* * *} \\
(0.064)\end{array}$ & $\begin{array}{c}0.569305^{* * *} \\
(0.058)\end{array}$ \\
\hline Grants & $\begin{array}{c}1.05884^{* * *} \\
(0.035)\end{array}$ & $\begin{array}{c}1.04526^{* * *} \\
(0.037)\end{array}$ & $\begin{array}{c}1.06255^{* * *} \\
(0.034)\end{array}$ & $\begin{array}{c}0.605089^{* * *} \\
(0.036)\end{array}$ & $\begin{array}{c}0.710909^{* * *} \\
(0.026)\end{array}$ \\
\hline Caprev & $\begin{array}{c}0.402122^{* * *} \\
(0.070)\end{array}$ & $\begin{array}{c}0.433169^{* * *} \\
(0.076)\end{array}$ & $\begin{array}{c}0.397581^{* * *} \\
(0.069)\end{array}$ & $\begin{array}{c}0.156535^{* * *} \\
(0.047)\end{array}$ & $\begin{array}{c}0.166286^{* * *} \\
(0.049)\end{array}$ \\
\hline Capex & - & - & - & $\begin{array}{c}-0.323989^{* * *} \\
(0.025)\end{array}$ & $\begin{array}{c}-0.381613^{* * *} \\
(0.027)\end{array}$ \\
\hline Curex & $\begin{array}{c}-0.824887^{* * *} \\
(0.057)\end{array}$ & $\begin{array}{c}-0.945641^{* * *} \\
(0.051)\end{array}$ & $\begin{array}{c}-0.844597^{* * *} \\
(0.057)\end{array}$ & - & - \\
\hline Hausman test & 548.3 & 536 & 549 & 583 & 681 \\
\hline $\begin{array}{l}\text { Between std. } \\
\text { dev. }\end{array}$ & 0.31 & 0.31 & 0.31 & 0.29 & 0.29 \\
\hline Within std. dev. & 3.03 & 3.19 & 3.03 & 1.14 & 1.27 \\
\hline $\begin{array}{l}\text { Adjusted } \\
\text { R-squared }\end{array}$ & 0.74 & 0.73 & 0.75 & 0.91 & 0.90 \\
\hline $\begin{array}{l}\text { No. of. } \\
\text { observations }\end{array}$ & 1,230 & 1,230 & 1,230 & 1,230 & 1,230 \\
\hline
\end{tabular}

Note: ${ }^{* *}$ indicates significance at $1 \%$ level, ${ }^{* *}$ indicates significance at $5 \%$ level, ${ }^{*}$ indicates significance at $10 \%$ level, Robust (HAC) standard errors reported in parenthesis.

Source: ARIS, own calculations. 
Table 4

The Probability of Re-election

\begin{tabular}{|l|c|c|}
\hline & $\mathbf{1}$ & $\mathbf{2}$ \\
\hline const & $\begin{array}{c}-0.535040^{* * *} \\
(0.098)\end{array}$ & $\begin{array}{c}-6.65190^{* * *} \\
(0.808)\end{array}$ \\
\hline Capex & $\begin{array}{c}0.0682613^{* * *} \\
(0.013)\end{array}$ & $\begin{array}{c}0.0722088^{*} \\
(0.042)\end{array}$ \\
\hline Grants & $\begin{array}{c}-0.0896623^{* * *} \\
(0.012)\end{array}$ & $\begin{array}{c}-0.186142^{* * *} \\
(0.056)\end{array}$ \\
\hline Elect (t) & & $\begin{array}{c}6.73333^{* * *} \\
(0.712)\end{array}$ \\
\hline Taxrev & & $-\begin{array}{c}0.135315 \\
(0.085)\end{array}$ \\
\hline Curex & & $\begin{array}{c}0.177461^{* * *} \\
(0.057)\end{array}$ \\
\hline McFadden Pseudo R-squared & 0.04 & 0.57 \\
\hline No. of. observations & 1,435 & 1,435 \\
\hline
\end{tabular}

Note: ${ }^{* * *}$ indicates significance at $1 \%$ level, ${ }^{* *}$ indicates significance at $5 \%$ level, ${ }^{*}$ indicates significance at $10 \%$ level, Robust (QML) standard errors reported in parentheses.

Source: ARIS, own calculations.

The results summarized in Table 4 clearly confirm that the increase in capital expenditures does not significantly increase the probability of re-election. At the same time, the increase in current expenditures may in fact increase the probability of re-election.

This suggests that the voters behave differently than politicians expect. Politicians try to influence the voters through increased capital expenditures, i.e. a strategy that works well in some other countries (e.g. Veiga and Veiga, 2007b, Akhmedov and Zhuravskaya, 2004, Drazen and Elsava, 2005 or Sakurai and Menezes-Filho, 2008), but it enjoys only limited success in the Czech Republic.

This can be explained as follows: The position of the incumbent in some municipalities is so strong that re-election is certain; therefore the incumbent does not need to engage in pre-election expenditure manipulation. In the case of incumbents with a weaker position, uncertain of re-election, they may engage massively in pre-election expenditure manipulation, but its impact on voters' behaviour is uncertain.

Sizeable capital investment projects can be perceived by voters in two opposite ways. The expenditures can be seen as a contribution for the community and as a product of an efficient current incumbent, i.e. as a reason for re-election. Or, on the other hand, they can be seen as a source of corruption of the current incumbent and friendly subjects, i.e. as a reason for voting someone new. This depends on how corruption is perceived in each municipality and how the media interpret it. If, for example, local newspapers permanently stigmatize some public contracts as doubtful, it will usually have a negative impact on the voters' decisions. We suppose that the main reason for the limited impact of increased capital expenditures on re-election is the widespread suspicions that the major beneficiaries of the realized projects were municipal politicians and their friends (see Štětka, 2010). 


\section{Conclusions}

Politicians aim for re-election and use all the tools at their disposal in order to increase their re-election chances. Our findings confirm the opportunistic behaviour of Czech incumbents as they manipulate public expenditures prior to elections. Due to the limited fiscal autonomy of the Czech municipalities, local incumbents cannot influence voters by the manipulation of taxes. They decrease current expenditures to invoke budget savings that can be used later on for more visible increases in expenditures. Subsequently, they increase capital expenditures significantly, mainly in the year of elections in the belief that they will signal their effectiveness and attract more voters. We suspect that capital expenditures are reduced after elections. However, our results also suggest that politicians are not successful in enhancing their chances for reelection through increased capital expenditures. We suppose that this is caused by a high degree of perceived corruption at the municipal level. Hence, we offer the important conclusion that Czech incumbents are guilty of irrational behaviour. In spite of that, we conclude that there is clear evidence of the presence of political business cycles in Czech municipalities.

\section{References}

Arellano, M. (2003), Panel Data Econometrics. Oxford: Oxford University Press.

Akhmedov, A., Zhuravskaya, E. (2004), "Opportunistic Political Cycles: Test in a Young Democracy Setting." Quarterly Journal of Economics, Vol. 119, pp. 1301-38.

Balík, S. (2008), Česká komunálni politika v obcích s rozšířenou působností: koalice, voličské vzorce a politické strany na místní úrovni v letech 1994-2006 (Czech Communal Politics in Municipalities of Extended Scope: Coalitions, Voter Patterns and Political Parties at the Local Level in the Years 1994-2006, text in Czech). Brno: Centrum pro studium demokracie a kultury.

Cerda R., Vergara R. (2007), "Business Cycle and Political Election Outcomes: Evidence from the Chilean Democracy." Public Choice, Vol. 132, pp. 125-36.

Drazen A., Eslava M. (2005), "Electoral Manipulation via Voter-Friendly Spending: Theory and Evidence.” NBER Working Paper, 11085.

Hemmings, P. (2006), "Improving Public-Spending Efficiency in Czech Regions and Municipalities." Economic Department Working Papers, No. 499. Paris: OECD.

Judson, R., Owen, A. (1996), "Estimating Dynamic Panel Data Models: A Guide for Macroeconomists." Economic Letters, Vol. 65, pp. 9-15.

Nordhaus, W. D. (1975), "The Political Business Cycle." Review of Economic Studies, No. 2, pp. $169-190$.

Nordhaus, W. D. (1989), "Alternative Approaches to the Political Business Cycle." Brookings Papers on Economic Activity, Vol. 1989, No. 2, pp. 1-68.

Oates, W. E. (1991), "Fiskální federalismus: Přehled teoretického výzkumu a praktických výsledkư" (Fiscal Federalism: Review of Theoretical Research and Practical Results, text in Czech). Finance a úvěr, Vol. 41, No. 6, pp. 261-77.

Rogoff, K., Sibert, A. (1988), "Elections and Macroeconomic Policy Cycles." Review of Economic Studies, Vol. 55, No. 1, pp. 1-16.

Rogoff, K. (1990), "Equilibrium Political Budget Cycles." The American Economic Review, Vol. 80, No. 1, pp. 21-36.

Rosenberg J. (1992), "Rationality and the Political Business Cycle: The Case of Local Government." Public Choice, Vol. 73, pp. 71-81.

Sakurai S., Menezes-Filho N. (2008), "Fiscal Policy and Reelection in Brazilian Municipalities." Public Choice, Vol. 137, pp. 301-14. 
Štětka, J. (2010), "Starostové, prachy, kmotři" (Mayors, Money, Godfathers, text in Czech). Ekonom, No. 41 , pp. 12-15.

Štiková R. (2008), "Models of Political Cycles: The Czech Experience." Prague Economic Papers, Vol. 15, No. 3, pp. 213-29.

Veiga, L. G. a Veiga, F. J. (2007), "Political Business Cycles at the Municipal Level." Public Choice, Vol. 131, pp. 45-64.

Veiga, L. G. a Veiga, F. J (2007b), “Does Opportunism Pay off?” Economic letters, Vol. 96, No. 2, pp. 177-82.

Žák, M. (1998), "Politicko-ekonomický cyklus." (Political Business Cycle, text in Czech) Politická ekonomie, 1998, Vol. 4, pp. 471-80. 